\title{
Sepsis, an Old Problem for Clinicians
}

\section{Edmond Puca*}

Service of Infectious Diseases, University Hospital Center, Tirane, Albania

"Corresponding author: Edmond Puca, Service of Infectious Diseases, University Hospital Center, Tirane, Albania, Tel: 0672058624; E-mail: edmond_puca@yahoo.com

\section{Received date: December 29, 2016; Accepted date: January 5, 2017; Published date: January 10, 2017}

Copyright: (c) 2017 Puca E. This is an open-access article distributed under the terms of the Creative Commons Attribution License, which permits unrestricted use, distribution, and reproduction in any medium, provided the original author and source are credited.

\section{Editorial}

Sepsis is a syndrome old as life itself. This syndrome has accompanied human evolution for generations. Ranging from antiquity to the nowadays sepsis definition has gone through several stages. However, the definition and methodology of studying was developed in the last decades. In spite of numerous, high cost studies its physiopathology is still not entirely understood. On the other hand it is quite clear that it is a dynamic heterogeneous disease which leads to a disbalance of the inflammatory network [1]. Nowadays, sepsis diagnostic methods are of extreme importance, not only for following its progress but moreover for establishing a diagnosis as soon as possible. It is an uncommon systemic reaction as a result of a microbe or its toxins. Despite modern technology in sepsis diagnosis, it still remains a potentially lethal and a very high cost syndrome for the health system [2]. Many studies reported a decline in sepsis mortality in recent years from $37 \%$ to $31 \%$ but again these figures remain high [1-3]. The reasons why the number of sepsis cases is increasing significantly are numerous such as age and other non-modifiable factors. Increased life expectancy has increased the number of patients in the intensive care units (ICU). Other pathologies such as neoplastic, autoimmune, accidents, long term hospital stay and the use of invasive devices are already factors predisposing to sepsis despite patients age [4]. The clinician doctor is the one who must approach appropriately and as soon as possible for early sepsis diagnosis and efficient treatment of. So thanks to the hard work of Dr. Roger C Bones and his colleagues since 1991 we have a definition of sepsis by the following table [5].

\begin{tabular}{|l|}
\hline Two or more of the following are required: \\
\hline - Body temperature $>38^{\circ} \mathrm{C}$ or $<36^{\circ} \mathrm{C}$ \\
\hline - Heart rate $>90$ beats $/ \mathrm{min}$ \\
$\begin{array}{l}\text { - Respiratory rate }>20 \text { breaths } / \mathrm{min} \text { (or arterial } \mathrm{pCO}_{2}<32 \mathrm{mmHg} \text {, indicating } \\
\text { hyperventilation) }\end{array}$ \\
\hline White blood cell count $>12.0 \times 10^{9} / \mathrm{L}$ or $<4.0 \times 10^{9} / \mathrm{L}$ (or $>10 \%$ immature forms) \\
\hline Sepsis=Infection+SIRS \\
\hline Severe sepsis=Sepsis+evidence of organ dysfunction. \\
\hline
\end{tabular}

Table 1. Definitions of sepsis. (American College of Chest Physicians/ Society of Critical Care Medicine Consensus Conference)

Later in time other criteria where added to sepsis evaluation, such as lactate and two other important markers PCR and PTC. It was the evaluation of sepsis physiopathology that made it possible and necessary for assessing other factors in its diagnosis and prognosis. Based on the data from numerous components which play a role in the inflammatory processes more indicators were monitored for the establishment and progress of patients with sepsis. There are currently more than 170 proposed indicators to diagnose and monitor the progress of patients with sepsis [6]. But are these many markers necessary and relevant? Pro-inflammatory and inflammatory cytokines are studied to follow the progress of patients with sepsis [1]. Cytokines are regulatory of the immune system and play an important role in inflammation. It is important for the clinician to have on hand a good marker for sepsis. A good marker would be one which can detect the infection early in its course and easily and have a high sensitivity and specificity, but a low high cost. Unfortunately such marker is still difficult to detect, except for lactate $[1,6]$. So far two markers such as CRP and Procalcitonin have shown good efficacy in identification and monitoring the progress of sepsis. Both these markers are not ideal but they are helpful in correlation with the patient's clinical situation to establish the diagnosis of sepsis [7-10]. CRP and procalcitonin are two most used tests in diagnosis and follow up. Both these markers are released into the blood as a result of infections or inflammatory processes [2]. Another marker similar to CRP is Pentraxin 3 (PTX3) which it is released by inflammatory cells. Comparing the three markers, the first two CRP and PCT are the most tested and studied for sepsis diagnosis. C-reactive protein (CRP) is an acute phase protein that is released by the hepatic cells after inflammation or tissue damage. It has a pro and anti-inflammatory role. Researches in the genetic studies of sepsis seem to be the future in its diagnosis. Maybe development of organ specific delivery of non-coding RNA mediators may be a promising approach as a biomarker and in therapeutic of sepsis.

\section{References}

1. Chaudhry H, Zhou J, Zhong Y, Ali MM, McGuire F, et al. (2013) Role of cytokines as a double-edged sword in sepsis. Vivo Athens Greece 27: 669-684.

2. Faix JD (2013) Biomarkers of sepsis. Crit Rev Clin Lab Sci 50: 23-36.

3. Hall MJ, Williams SN, DeFrances CJ, Golosinskiy A (2011) Inpatient care for septicemia or sepsis: a challenge for patients and hospitals. NCHS Data Brief 62: 1-8.

4. Ho J, Chan H, Wong SH, Wang MHT, Yu J, et al. (2016) The involvement of regulatory non-coding RNAs in sepsis: a systematic review. Crit Care Lond Engl 28; 20: 383.

5. American College of Chest Physicians/Society of Critical Care Medicine Consensus Conference: definitions for sepsis and organ failure and guidelines for the use of innovative therapies in sepsis. Crit Care Med 20: 864-874.

6. Pierrakos C, Vincent JL (2010) Sepsis biomarkers: a review. Crit Care Lond Engl 14: R15.

7. Ryu JA, Yang JH, Lee D, Park CM, Suh GY, et al. (2015) Clinical usefulness of procalcitonin and c-reactive protein as outcome predictors in critically ill patients with severe sepsis and septic shock. PLoS ONE 14; 10. 
Citation: Puca E (2017) Sepsis, an Old Problem for Clinicians. Clin Microbiol 6: e138. doi:10.4172/2327-5073.1000e138

Page 2 of 2

8. Reinhart K, Bauer M, Riedemann NC, Hartog CS (2012) New approaches to sepsis: molecular diagnostics and biomarkers. Clin Microbiol Rev 25: 609-634.

9. Bloos F, Reinhart K (2014) Rapid diagnosis of sepsis. Virulence. 1; 5: 154-160.
10. Gomes AP, Miguel PSB, Alves DLS, Inoue VH, Oliveira AP, et al. (2015) Pro-inflammatory cytokines in sepsis: biological studies and prospects from in silico research. Biol Syst Open Access 5: 158. 